\title{
Monarkiet i Norden 1814-1914
}

I anledning af 200-airet for freden $i$ Kiel i januar 1814, hvor DanmarkNorge under Frederik 6. måtte afstå Norge til Sverige, hvorved unionen imellem de to lande fra 1380 sprengtes, afholdt Det Kongelige Bibliotek en foredragsrakke om "Danmark-Norge for og efter 1814". Disse foredrag bringes i let redigeret udgave i Magasin. Denne artikel om Monarkiet i Norden 1814-1914 er den syvende i rekken.

afprofessor mso, ph.d. Jes Fabricius Moller, Grundtvigcentret, Aarhus Universitet

$\mathrm{P}$ å den norske nationaldag den 17. maj fejres hvert år Eidsvollforfatningen. Det interessante er, at den 17. maj slet ikke er årsdagen for den norske forfatning. Den blev vedtaget allerede dagen før. Den 17. maj fik Norge sin selvstændighed, idet prins Christian Frederik blev valgt til konge, og grundloven blev endeligt underskrevet og dateret. Selve begivenheden den 17. maj rummer i hvert fald to afgørende elementer. For det første er den vidnesbyrd om kongemagtens betydning for staten. Den norske stats selvstændighed blev virkelig i det øjeblik, en monark blev udpeget. For det andet er den udtryk for en fuldstændig omvæltning af monarkiets natur. Christian Frederik arvede ikke den norske trone. Han var ikke født til embedet. Han blev udpeget. Det var helt i overensstemmelse med det princip, som modefilosoffen Immanuel Kant havde gjort gældende: Staten var ifølge Kant selvberoende og ikke-dynastisk, et samfund af mennesker, over hvilket ingen andre end den selv kunne råde og disponere. Staten kunne ikke i kraft af dynastiske forbindelser og arv indgå i en anden stat. Staten erhverver en regent, ikke omvendt. ${ }^{1}$

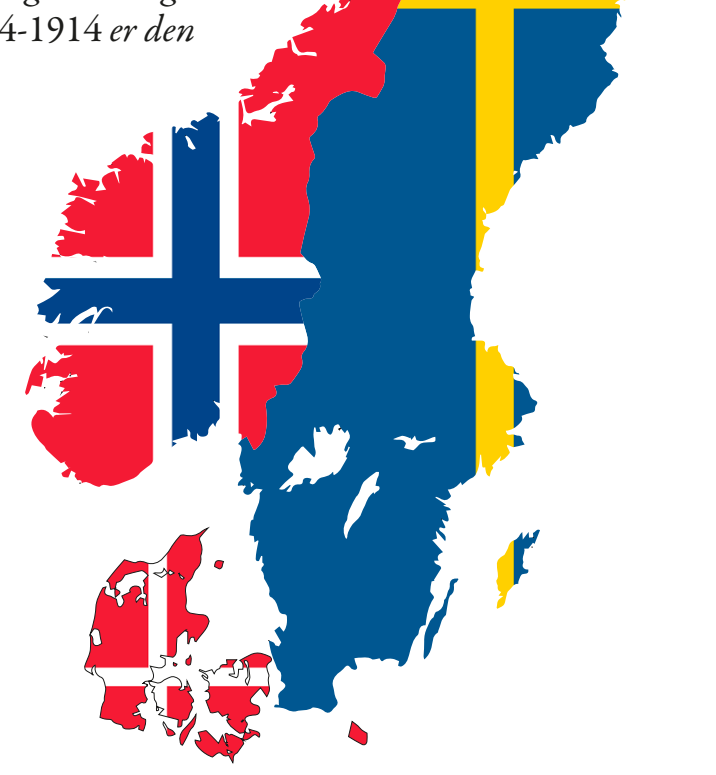

Den norske selvstændighed i 1814 var med andre ord revolutionær, men også traditionel. Den var traditionel i den forstand, at den unge, selvstændige norske stat ikke kunne forestille sig sin selvstændighed på anden måde end ved "at gjenrejse Norges gamle Kongestol". ${ }^{2}$ Den var revolutionær i den forstand, at monarken ikke tiltrådte sit embede i kraft af arv, men fordi han blev valgt til det af Eidsvollmændene. Han var i virkeligheden en slags præsident valgt ved indirekte valg.

Denne revolutionære omkalfatring af kongens rolle og betydning var et resultat af de forudgående 25 års europæiske historie. Den franske revolution blev i mange kredse indledningsvis modtaget 
med nysgerrighed og positiv interesse, fordi den byggede på de principper om folkesuverænitet, borgerlige rettigheder og lighed for loven, som havde cirkuleret i den europæiske borgerlige offentlighed. Juristerne blandt Eidsvollmændene var alle uddannet i København, hvor de på den enevældige konges universitet havde faet kendskab til den nyeste statsretsteori. ${ }^{3}$

Men allerede få år efter udbruddet af revolutionen var det dominerende syn på selve revolutionen negativt. Den havde vendt op og ned på verdensordenen, eller rettere ødelagt den kendte orden uden at erstatte den med en anden.

\section{C6 m Anfang war Napoleon." $A$ Med denne sætning indledte 1 Thomas Nipperdey første} kapitel af sit store tobindsværk om Tyskland i det 19. århundrede. Napoleon bemægtigede sig først revolutionen, dernæst store dele af Europa, hvem han påførte de revolutionære principper i en transformeret udgave. Med henblik på Tyskland kaldte Nipperdey det en "Fürstenrevolution". ${ }^{4}$ Den begyndte med Napoleon selv, en self-made man, general i revolutionshæren, en parvenu, der endte med at genindføre monarkiet i Frankrig med sig selv som kejser. Han savnede enhver form for traditionel dynastisk legitimet som fyrste, og hans erobringspolitik var upåvirket af gældende principper om territorial integritet. Men da først hans magt var etableret, konsoliderede han den ved at opføre sig fuldstændig, som om han var en traditionel dynastisk hersker. Han skilte sig af med sin borgerligt fødte kone og giftede sig ind i en betydelig fyrsteslægt, og han indsatte sine slægtninge som fyrster i de franske lydlande. I Tyskland blev gamle fyrstendøm- mer opløst, især de gejstlige, og opslugt af andre. Lande som Württemberg, Bayern og Baden voksede dermed i størrelse og blev mellemstore stater, hvis monarker ganske vist havde den fyrstelige stamtavle i orden, men hvis størrelse og status var et resultat af ren Machtpolitik.

Det samme mønster kan genkendes i, hvad vi i dag kalder Norden. Det omfattede o. 1800 to monarkier: det svenske og det danske. "Svensk" og "dansk" dækker som begreber kun nødtørftigt, hvad der er tale om. ${ }^{5}$ Harald Gustafsson har introduceret begrebet konglomeratstat om den tids statsdannelser (en variant af den i den engelsksprogede litteratur gængse betegnelse composite state), altså en statslig enhed sammensat af bl.a. juridisk, etnisk, socialt og økonomisk forskellige regioner bundet sammen af fyrsten som person og institution.

Danmarks direkte inddragelse i Napoleonskrigene fandt som bekendt sted i 1801. Den britiske flåde dukkede op i Øresund med kravet om dansk udtrædelse af det væbnede neutralitetsforbund. I 1807 dukkede briterne op igen, denne gang med fuld styrke i det, der på det tidspunkt var en af verdenshistoriens største amfibieoperationer. Det var ikke verdenshistoriens første bombardement af en civilbefolkning, som det ofte er blevet påstået i den hjemlige litteratur. Det franske bombardement af Bruxelles i 1695 skal blot nævnes som et eksempel. Denne gang lykkedes det briterne at påføre danskerne et entydigt nederlag takket være en overvældende styrkeposition. ${ }^{6}$

Det følgende år udløstes krigen mellem Sverige og Rusland, der endte med store territoriale afståelser til Rusland. Samtidig var der i Sverige opstået et dynastisk problem, idet den svenske tronfølger døde 


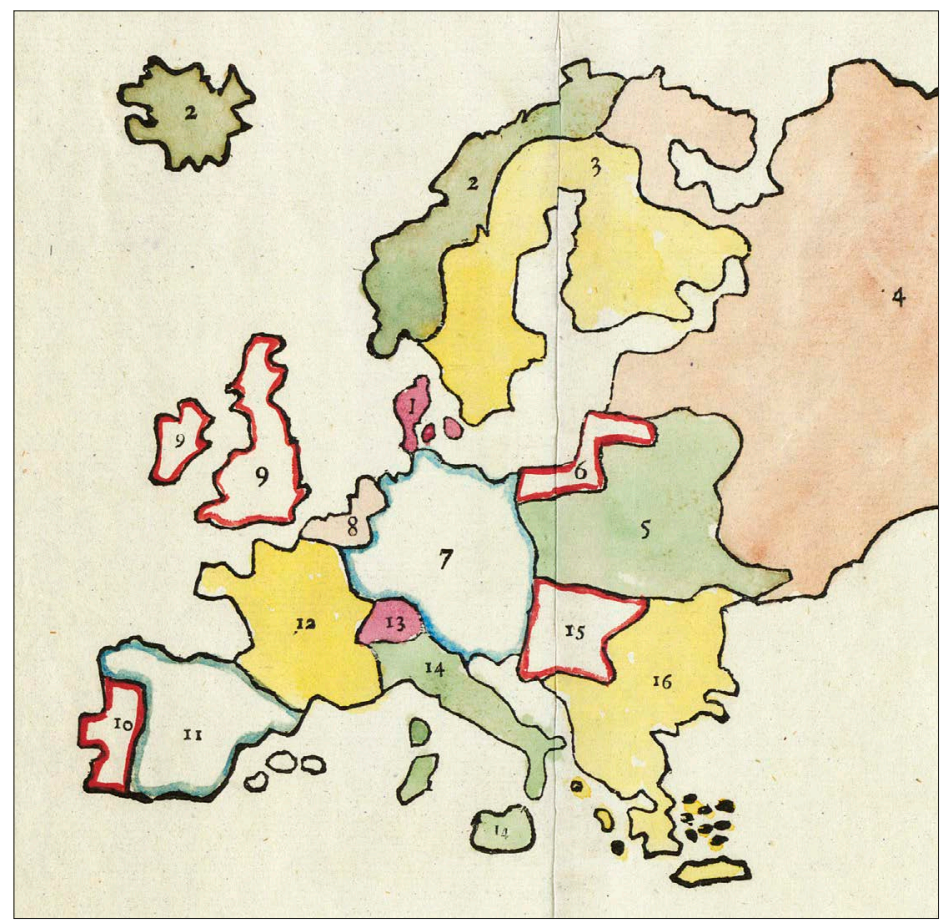

Anton Frantz Just:

Kort over Europa

år 1800 (udsnit).

Kortet folger skif-

tevis statsretlige og

nationale grenser.

Sverige og Finland

udgor statsretligt et

hele, mens Dan-

mark-Norge angives

at vere to forskellige

lande. Det tyske

kejserrige bestod

endnu formelt ar

1800, mens f.eks.

Italien var et kon-

glomerat af storre og

mindre stater. Det

Kongelige Bibliotek,

Kortsamlingen.

i 1810, og Sverige stod uden tronarving. Flere kandidater var på tale, men valget faldt noget overraskende på fyrsten af Ponte-Corvo og Jean-Baptiste Bernadotte. Han var borgerligt født i 1763 i Pau i det sydvestlige Frankrig, valgte officersvejen, gjorde strålende karriere i Napoleons hære og blev belønnet med en fin titel. Samtidig havde han giftet sig med Napoleons tidligere forlovede, Desirée, et ægteskab, der ganske vist var lige så borgerligt som hans herkomst, men som bragte ham i en slags direkte dynastisk forbindelse til kejseren selv. Det anvendte han som springbræt til at bringe sig i stilling som tronfølger i Sverige. Da han imidlertid først havde anbragt sig dér, førte han Sverige bort fra alliancekursen med Frankrig.

Bernadotte var som Napoleon en parvenu, en opkomling, men som tronarving og siden svensk-norsk konge gjorde han alt for at underbygge Bernadotte-familiens dynastiske legitimitet, samtidig med at han sørgede for at skabe stærke alliancer med borgerlige kredse i Sverige. ${ }^{7}$

Et af de blivende fænomener, som Napoleon efterlod sig, også i de lande, han ikke erobrede, var en omfattende kodificering af retstilstanden, både statsretligt og civilretligt. Sverige fik en forfatning $i$ 1809 , Norge fik sin i 1814, og i løbet af et årti havde flertallet af europæiske stater fået en moderne forfatning, og i $1850 \mathrm{var}$ det kun Storbritannien og Rusland, der ikke havde en nedskrevet forfatning. For briternes vedkommende handlede det om, at udviklingen af et konstitutionelt monarki foregik organisk, og for russerne var der tale om, at enevælden blev fastholdt langt ud over sidste holdbarhedsdato. 
Den såkaldte restaurationsperiode efter Wienerkongressen 1815 var med andre ord ikke de europæiske monarkiers Indian Summer, en terminal- eller overgangsfase inden demokratiets og/ eller republikkens endelige frembrud. ${ }^{8}$ Det Europa, der blev til efter Napoleon, var ikke bygget op på trods af monarkerne, men i kraft af dem og ved hjælp af dem. Det borgerlige århundrede var med Dieter Langewiesches ord fyrstestaternes århundrede.

"Dieses neue Europa, an dessen Beginn eine Gewalt steht, die legitime Herrschaft vernichtete und zugleich eine Ära der Revolution und des ständigen Krieges beendete, blieb - trotz Revolution, trotz Staatszerstörung und Staatserschaffung - ein Europa der Dynastien. Kein neuer Staat entstand damals ohne fürstliches Haupt. Das bürgerliche Säkulum wurde zu einem Jahrhundert der Fürstenstaaten."

Det nye var ikke, at monarkiet som stats- eller styreform forblev normen, men at monarkierne næsten overalt blev konstitutionelle. Foregangsland var Frankrig, der således fortsatte med at udgøre udgangspunktet for de revolutionære omvæltninger. La Charte Constitutionelle fra 1814 dannede forbillede for den række af konstitutioner, som blev udbredt i Europa efter 1815. Hverken den spanske af 1812, dens svenske af 1809 eller Eidsvollforfatningen af 1814 havde den samme indflydelse. ${ }^{10}$

Den franske forfatning blev givet efter en konflikt mellem senatet og den designerede tronfølger. Det var senatet, der formelt havde afsat Napoleon og nu ønskede at genindsætte Bourbon'erne på tronen. Imidlertid lod den udsete tronkandidat, Louis-Stanislas Xavier, comte de Provence, sig ikke indsætte, men betragtede sig fra første færd som den lovlige konge, Ludvig 18., og han handlede ud fra den grundsætning, der blev kendt som det monarkiske princip, det vil sige, at al statsmagt udgår fra kongen. Hvis Frankrig skulle have en forfatning, skulle den gives af ham, og det lykkedes ham at sætte sin vilje igennem over for senatet. Den 2. maj 1814 udstedte han løfte om at give Frankrig une constitution libérale. ${ }^{11}$

Hvad man skal lægge i prædikatet libérale er naturligvis afgørende. ${ }^{12}$ Jörn Leonhard mener, at det som begreb anvendt i 1814 var løsrevet fra associationer til den franske revolution og kendetegnede politiske ønsker om reformer i almindelighed, og liberal "blev den fremherskende oppositionsetiket". ${ }^{13}$ Den iagttagelse bekræftes af den brug, som constitution libérale fik i den danske oversættelse. "En fri forfatning" blev et begreb, der havde tilstrækkelig med prægnans og signalværdi til at fungere som emblem for ønsket om forbedringer i et samfund, der havde en meget klar oplevelse af at befinde sig $i$ et tidehverv, i en overgangsfase mellem gammelt og nyt. ${ }^{14}$

$\boldsymbol{C}^{\mathrm{t}}$ $t$ af de afgørende resultater af Wienerkongressen var skabelsen af Det Tyske Forbund. I forbundsaktens artikel 13 stod følgende bestemmelse: "In allen Bundesstaaten wird eine landständische Verfassung stattfinden" Der var ikke angivet nogen tidsfrist, og indholdet blev ikke nærmere specificeret, men bestemmelsen havde afgørende indebyrd for det danske monarki, idet både Lauenborg og Holsten indgik i det tyske forbund. ${ }^{15}$

Forfatningsdiskussionen også i det oldenborgske monarki gik i gang med det samme. Allerede i 1816 havde Niels Falck, juraprofessor i Kiel, udgivet sine betragt- 
ninger om hertugdømmernes forfatningsretlige stilling, motiveret af ønsket om "Wiederherstellung der Landstände oder Einführung einer verbesserten Volksrepräsentation", en indirekte henvisning til forbundsakten. ${ }^{16}$ Indholdet af hans traktat gik stik imod den herskende opfattelse af især Slesvigs statsretlige status og udfordrede endda det monarkiske princip, idet han mente, at det var de før-enevældige håndfæstninger, der skulle bestemme Slesvigs forhold til henholdsvis kongeriget og Holsten.

Uwe Jens Lornsens forfatningsudkast fra 1830 betragtes som startskuddet til liberalismens opblomstring, men der er grund til at gøre opmærksom på, at Lornsen ikke var uden forløbere, som f.eks. Falck. Også Lornsens skrift var udtrykkeligt motiveret af forbundsaktens for Holsten endnu uopfyldte 13. artikel, "worin die sämmtlichen Fürsten Deutschlands ihren Ländern repräsentative Verfassungen zusichern", som han udlagde teksten. ${ }^{17}$

Frederik 6. var direkte forpligtet af Forbundsakten, idet både Holsten og det til monarkiet nytilkomne Lauenborg, som han havde mageskiftet sig til efter Freden i Kiel, var medlemmer af Det Tyske Forbund. Det var givet, at han med Stænderforordningen af 1831 mente at have opfyldt løfteparagraffen og dermed lagt låg på det konstitutionelle røre, hvilket som bekendt ikke var tilfældet. Frederik 6. var ingen reformtilhænger, men man skal i den sammenhæng være opmærksom på, at han slet ikke gik ind for et vilkårligt eller retsløst samfund. Når den enevældige stat i ganske få undtagelsestilfælde greb til at eksekvere dødsdomme for andet end morddømte, skete det med kongens ord som et forsvar for "den borgerlige orden", ikke den fyrstelige. ${ }^{18}$
Da prins Christian Frederik overtog tronen med kongenavnet Christian 8. i 1839 , vakte det håb om gennemgribende reformer, fordi han havde stået fadder til Eidsvollforfatningen. I litteraturen beskrives han ofte som en skuffelse. Det er ikke en ganske retfærdig dom. Han gennemførte i sine første regeringsår en gennemgribende kommunalreform, der gav borgere og jordejere en betydelig andel i sognekommunernes og købstædernes bestyrelse, og i 1841 udkom det første samlede statsbudget på tryk, "samtlige Stats-Indtægter og Udgifter, vedkommende Kongeriget Danmark og Hertugdømmerne Slesvig, Holsteen og Lauenborg, med tilhørende Bilande" trykt dengang som nu hos Schultz. Når kongen ikke kunne imødekomme ønsket om en fælles forfatning for sit monarki, var det naturligvis, fordi det slesvigske problem stod i vejen.

Presset steg på Christian 8. gennem 1840 'erne. I 1847 var kongen ikke engang tæt på at indføre reformer, der kunne tilfredsstille de nationalliberale krav. Han havde selv forestillet sig et Statsråd efter preussisk forbillede, altså en gruppe udpeget af ham selv, en slags kongeligt senat med lovgivende og dømmende myndighed. ${ }^{19}$

Da det tidligt i januar 1848 stod kongen klart, at han skulle dø, vidste han også, at det dynastiske problem som følge af hans død ville gøre den politiske situation endnu mere anspændt, så han skrev et politisk testamente til sin $s ø n$, i hvilket han pålagde ham at gifte sig standsmæssigt, det vil sige løse det dynastiske problem, og endvidere "ved sin Regierings Tiltrædelse at tilsige det danske Folk og Hertugdømmerne en fælles constitutionel Forfatning, som han forbeholder nærmere at give disse hans Arvelande". 20 
Det var et eklatant udtryk for, at kongen efterlod sig en opgave, som han ikke selv havde magtet at løse. Den gordiske knude bestod i, at den konstitutionelle bevægelse havde knyttet sig stærkt til den nationale. Kravet om Danmark til Ejderen gik hånd $i$ hånd med kravet om en fri forfatning. De nationalliberale ønskede sig måske ikke et demokrati, men man kan godt beskrive deres ambitioner som et ønske om at indføre konstitutionelt etnokrati. Det vil sige, at ethvert forsøg på at give Helstaten en fællesforfatning ville møde modstand fra de nationale bevægelser.

Den nytiltrådte konge, Frederik 7 ., valgte ved et møde i Statsrådet den 22. marts 1848 at betegne sig selv som 'konstitutionel monark. ${ }^{21}$ Men da Grundloven skulle formuleres, valgte man at bruge betegnelsen 'indskrænket monarkisk' om styreformen.

Den danske enevælde var som bekendt allerede afskaffet en gang før, nemlig i Norge i 1814, og det er interessant at iagttage, at den norske grundlovs første paragraf anvender præcis samme betegnelse for den valgte regeringsform: "Kongeriget Norge er et frit, uafhængigt og udeleligt Rige. Dets Regjeringsform er indskrænket og arvelig monarkisk." ${ }^{22}$ Det indskrænkede monarki har som styreform i påfaldende grad været ignoreret i historievidenskaben og statsforfatningsretten. Som regel afskrives fænomenet som et røgslør, man lagde ud for at skjule, hvad det var, man i virkeligheden havde gang i. ${ }^{23}$ Men begrebet var veletableret i den statsretlige litteratur, og det indebar en klar forståelse af, at kongemagten ikke var irrelevant. ${ }^{24}$ Det blev også ganske tydeligt udtrykt i Eidsvollmændenes henvendelse til Christian Frederik i 1814, hvori de skrev, at hensigten var "at fordele den souveraine Magt saaledes, at Lovgivningen nedlægges i Folkets, og den udøvende Magt i Kongens Haand." I sit svar anerkendte kongen visdommen i denne fordeling, fordi man dermed sikrede borgerfrihed og "den Orden i Staten, som den udøvende Magt er pligtig og formaaende til at vedligeholde." Samtidig sikrede denne fordeling "at vogte Regjeringsformen for Despotismens Kjendemærker, og for Folkeregjeringens Misbrug." ${ }^{25}$

Paragraf to i Junigrundloven af 1849 definerede de indskrænkninger, der skete i kongens enevældige magt: "Den lovgivende Magt er hos Kongen og Rigsdagen i Forening. Den udøvende Magt er hos Kongen. Den dømmende Magt er hos Domstolene."

Der er tale om en meget klar formulering. Kongen måtte helt opgive sit forsæde i Højesteret. Det havde han ganske vist ikke gjort anvendelse af i praksis siden 1740'erne, og det danske retsvæsen havde allerede inden 1848 udviklet en betydelig grad af selvstændighed i forholdet til kongemagten. ${ }^{26}$ Kongen kunne dog stadig benåde. Til gengæld beholdt kongen den udøvende magt, mens han måtte dele den lovgivende med Rigsdagen. Kongen kunne opløse Rigsdagen eller hvert af tingene ( $\$ 27)$, og hans samtykke krævedes for, at en lov skulle have gyldighed (\$29). Kongen kunne endvidere i nødstilfælde give foreløbige love (\$ 30).

Selvom styreformen var den samme som i Eidsvollforfatningen, var den danske grundlov væsentlig mindre revolutionær af karakter. Frederik 7. blev iscenesat og siden husket som "Grundlovens Giver”. Han var som person i mange henseender en statist, men han beklædte stadig et embede, som næppe kunne afskrives som irrelevant. Det blev tydeligt i det slesvigske spørgsmål. 
$\mathrm{D}$ er blev udkæmpet to krige (184850 og 1864) om Slesvig. Konflikten blev nærmest definerende for Danmark i de følgende 100 år, mens den er stort set glemt i Tyskland, selv om den udgjorde det første trin af tre mod skabelsen af det andet tyske kejserrige i $1871 .{ }^{27}$

Selvom den slesvigske konflikt udviklede sig med det nationale spørgsmål som væsentligste drivkraft, var den udløsende faktor det dynastiske problem, som Christian 8. havde bedt sin søn om at få løst. Det gjorde han blot ikke. Det stod allerede omkring 1850 fast, at Frederik 7. antagelig ville dø barnløs, og dermed var den oldenborgske kongeslægts mandsstamme i praksis uddød. Det danske monarki stod foran opløsning, fordi der var uenighed om arvefølgen $\mathrm{i}$ kongeriget på den ene side og hertugdømmerne på den anden. I kongeriget kunne tronen arves på mødrene side, mens det var den fremherskende holdning især i Holsten, at der her kun gjaldt ren mandlig arvefølge. Man måtte finde en kandidat, der ikke alene havde den dynastiske legitimitet det vil sige var tilstrækkelig nært beslægtet med den regerende konge - men tillige var politisk acceptabel i Danmark og ikke mindst spiselig for stormagterne.

Der havde nemlig efter Wienerkongressen udviklet sig, hvad man kalder den europæiske koncert eller det europæiske pentarki bestående af de fem stormagter Rusland, Preussen, Østrig, Frankrig og Storbritannien, som havde formået at bevare en indbyrdes magtbalance, der havde sikret et hidtil nærmest uset fravær af krig i Europa efter 1815. Målet for denne balance var at opretholde status quo og dermed også det danske monarkis integritet, som man sagde. Sammenhængen mellem hertugdømmerne og kongeriget beskrives i den tyske litteratur ofte som en personalunion. Dette udtryk anvendes stort set aldrig i den danske litteratur i modsætning til den dansk-norske union frem til 1814, der med væsentlig større lethed lod sig definere som en personalunion. ${ }^{28}$ Hvorom alting er, var monarken det afgørende bindeled mellem hertugdømmerne og kongeriget. De fleste havde endnu opløsningen af den britisk-hannoveranske personalunion i $1837 \mathrm{i}$ frisk erindring. Det forholdt sig nemlig således, at på samme måde som den danske konge var medlem af Det Tyske Forbund i sin egenskab af hertug af Holsten og Lauenborg, var også den britiske monark frem til 1837 medlem af samme forbund i sin egenskab af konge af Hannover. Kongeriget Hannover var en af nyskabelserne som følge af Napoleonskrigene og Wienerkongressen, en fortsættelse af kurfyrstendømmet Braunschweig-Lüneburg, hvis fyrste havde besiddet den britiske trone siden 1714. I 1837 var den nærmeste arving til begge troner imidlertid en kvinde, og eftersom man i Hannover insisterede på ren mandlig arvefølge, mens man i Storbritannien også havde kvindelig arvefølge, måtte personalunionen opløses, idet den nærmeste arving, prinsesse Victoria, blev britisk dronning, mens den nærmeste mandlige arving, Ernst August, blev konge af Hannover.

Den danske arvefølge blev afgjort i London i 1852. Flere kandidater måtte udelukkes. Augustenborgerne var på mange måder de dynastisk nærmeste at tage, fordi de var direkte efterkommere af Christian 3. Derudover havde de opretholdt en ægteskabspolitik, der knyttede dem overordentlig tæt til det danske kongehus. Hertugen af Augustenborg, Christian August, og hans bror, Prinsen 
af Nør, havde imidlertid i kraft af deres rolle på slesvig-holstensk side i den første slesvigske krig dømt sig selv ude. Der var derfor kun tre muligheder tilbage: For det første var der Christian 8.'s søster, Louise Charlotte, og ikke mindst hendes børn med landgreve Wilhelm af Hessen. Christian 8. havde gerne set sin nevø, landgrevens eneste søn, Frederik af Hessen, som dansk tronfølger. Frederiks søster, Louise, var gift med den næste mulighed, en repræsentant for en af de øvrige hertugelige slægter, Christian af Glücksborg. Glücksborgerne er som Augustenborgerne efterkommere af Christian 3. Egentlig var Christians far, Wilhelm, hertug af Holsten-Beck, endnu en sidegren af de sønderjyske hertugslægter, men da den sidste Glücksborger døde i 1825, overtog Wilhelm glücksborgnavnet. Christian var ikke den ældste af Wilhelms sønner, men havde i modsætning til sine brødre tjent på dansk side under Den første slesvigske Krig, så han var den mest oplagte kandidat, hvis valget skulle falde på en Glücksborger. Men det skulle det slet ikke.

Valget mellem mulige kandidater tilkom i praksis den russiske zar af to grunde. Dels var zaren selv overhoved for den gottorpske fyrsteslægt, der i princippet var førstevælger, dels var han så altså også lige zar eller kejser af Rusland, Østersøens førende stormagt.

Man kunne ikke forvente at få en løsning igennem uden russernes samtykke. Kong Frederik 7. anmodede i dybeste fortrolighed gennem sin regering i 1849 zaren om at træffe et valg. Zaren gav som forventet afkald på sin egen ret til den danske trone. De øvrige stormagter ville aldrig have tolereret en personalunion mellem Rusland og Danmark. Zaren pegede i stedet på en yngre gren af den gottorpske fyrsteslægt, der pudsigt nok nu var storhertuger af Oldenborg. Det pudsige var, at de netop sad dér, mens de gjorde krav på den oldenborgske trone, altså den danske. Forklaringen er den, at Gottorperne, der som nævnt længe havde været de danske kongers stærkeste rivaler, ved et mageskifte var blevet tvunget ud af Holsten i 1773 og havde fået hertugdømmet Oldenborg i bytte. I sit svar, dateret 7. januar 1850, lod zaren den danske konge tilflyde meddelelse om, at valget nærmere bestemt var faldet på arvestorhertug Peter af Oldenborg.

Arvestorhertugen var ikke danskernes foretrukne kandidat, men man lagde sig fladt på maven for zarens ønske. Den danske konge "paaskønner levende den høje Upartiskhed og den ædle Aabenhjærtighed, der præger de vise Raad, som Kejseren har haft den Godhed at meddele ham i denne Sag. Hs. Majestæt vil altid bevare en dybtfølt Taknemmelighed derfor, og han bereder sig til at følge dem med ubegrænset Tillid", som det servilt blev formuleret i den danske svardepeche..$^{29}$ Arvestorhertugen gjorde sig imidlertid helt umulig i danske øjne, idet han fastholdt sine slesvig-holstenske sympatier, og således endte opgaven som dansk tronfølger hos prins Christian af Glücksborg.

Det var op ad bakke for "Protokolprinsen" eller "Hr. Beck", som han foragteligt blev kaldt. Hele ideen med at vælge ham som tronarving var, at han for det første var en løsning på et dynastisk problem, og at han for det andet opfyldte stormagternes ønske om at bevare status quo i Østersøregionen. Her gjorde man imidlertid regning uden de danske nationalliberale - og Bismarck må man tilføje. Kong Christian 9. var blevet valgt som et 
middel til bevarelse af det danske monarkis integritet, altså helstatens bevarelse, og var dermed ikke svaret på det nationale spørgsmål.

Ikke desto mindre blev han ved sin tiltrædelse i november 1863 tvunget til at skrive under på en grundlov, der i realiteten indebar en annullering af hans stillingsbeskrivelse, idet den såkaldte novemberforfatning var bygget på de nationalliberale principper om Danmark til Ejderen og ikke beskyttelsen af det danske monarkis integritet eller Helstaten, som man var begyndt at kalde hertugdømmerne og kongeriget under eet. Udfaldet er velkendt. Hvad end de danske politikeres ambitioner eller planer var, kan resultatet ikke tolkes som andet end et nederlag.

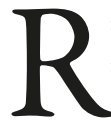

asmus Glenthøj understreger i sin analyse af 1864 , at den skandialternativ. ${ }^{30}$ Kalmarunionen var som idé aldrig helt død. Da det svenske tronfølgerspørgsmål blev åbnet i 1810, var det på tale at samle Sverige, Norge og Danmark under een krone. Med valget af en Augustenborger ville muligheden ikke have været så fjern. Under forhandlingerne om den danske tronfølge i begyndelsen af 1850 'erne plejede den svenske konge Oscar 1. ambitioner om at blive dansk tronfølger. Den nationalliberale utilfredshed med prins Christian af Glücksborg som dansk tronfølger førte i 1863 til sonderinger fra den danske regerings side om at lade Danmark og Sverige-Norge indgå en union. Forbilledet var den samtidige union af stater på den italienske halvø, som var blevet tilvejebragt i 1861, da kongen af Piemonte, Savoyen og Sardinien, Vittorio Emanuele, blev udråbt til konge af hele Italien. Parallellerne mellem Italien og Skandinavien er interessante. Sprog-

ligt, socialt og politisk var variationerne $i$ det forenede Italien ikke mindre end i Skandinavien, så en samlet skandinavisk statsdannelse var bestemt hverken mere eller mindre utænkelig end en italiensk. Svenskerne afviste imidlertid de danske tilnærmelser. ${ }^{31}$

Da den danske kronprins Frederik (senere den 8.) i 1868 blev forlovet med den svenske prinsesse Lovisa, kaldet Sessan, vakte det håb om en skandinavisk personalunion. Prinsesse Lovisa var nemlig enebarn, og et barn i dette ægteskab ville derfor i teorien blive arveberettiget til både den norske, svenske og danske trone. Forlovelsen blev erklæret af prinsessens far, Carl 15., under en hesteauktion i Bäckaskog i Skåne den 16. juli 1868. Også han så de skandinaviske perspektiver i ægteskabet. "Jeg kunde ej hjelpe Danmark under krigen, nu kan jeg give dem mit eneste Barn," sagde kongen..$^{32}$ Carl 15. havde i efteråret 1863 ganske vidtløftigt og uden sin regerings billigelse lovet danskerne militær støtte, en støtte, der som bekendt udeblev. Det havde ikke mindst geopolitiske årsager. Sverige grænsede på dette tidspunkt direkte op til Rusland og havde ingen interesse $i$ at åbne en anden front. ${ }^{33}$ Men skandinavismen forblev ikke blot en fjern drøm. Den blev virkeliggjort som en møntunion i 1875, da Norge, Sverige og Danmark samtidig indførte en fælles møntfod, kroner og øre. Den brød hurtigt sammen som møntunion betragtet, men betegnelsen for møntfoden er bevaret til i dag i alle tre lande.

Tor Boman Larsen har i sit værk om det moderne norske kongehus foreslået, at valget af den danske prins Carl som norsk konge under navnet Haakon i 1905 ses i en skandinavisk kontekst. ${ }^{34}$ 
En svensk prins blev med vilje fravalgt til fordel for en dansk, hvis mor imidlertid var svensk, den førnævnte kronprinsesse Lovisa. Der blev dog ikke noget af den personalunion, som nogle måske havde drømt om. Valget af prins Carl som ny norsk monark blev derimod rammen for en stærkt konsolideret, selvstændig norsk nationalstat - selv om den danskfødte kong Haakon aldrig fik lært sig at tale norsk. Det norske såvel som de fleste øvrige kongehuse havde på dette tidspunkt gennemført den omvending, som filosoffen Immanuel Kant havde beskrevet mere end hundrede år tidligere. De var blevet indlejret i staten, men nok så vigtigt var kongehusene også blevet nationaliseret. Det dynastiske ophav gled $i$ baggrunden til fordel for det nationale tilhørsforhold. Den glücksborgske gren af det oldenborgske kongehus blev nu til det norske, det danske og det græske kongehus. Den britiske kong Georg 5., der officielt var af fyrstehuset Saxen-Coburgund-Gotha, og hvis øvrige bedsteforældre tilhørte henholdsvis det hannoveranske, det hessen-kasselske og det glücksborgske hus, tog konsekvensen og omdøbte under Første Verdenskrig, da det ikke var så velset at være tysk i Storbritannien, sin familie til "Huset Windsor".

Mens ingen ny stat i det 19 . århundrede blev skabt uden et monarkisk overhoved, var det som bekendt helt anderledes i det 20., da monarkiet ikke længere kunne tages for givet. Republikanismen vandt også frem i Danmark, ligeledes især blandt socialdemokrater og de såkaldt kulturradikale. Som Jørgen Haugan har understreget, var København endnu på dette tidspunkt Norges kulturelle hovedstad: ${ }^{35}$ Alle de store norske digtere udkom på Gyldendal, hvis forlægger Peter Nansen i et brev til digteren og republikaneren Bjørnstjerne Bjørnsson skrev:

"Danmark er af Vorherre indstiftet til det Land, der skal bevare det monarkiske Princip til Dagenes Ende. Naar hele den øvrige Verden har givet sine Monarker Afsked, vil Danmark bevares som det lille forhistoriske Land med en Æventyrkonge, der paa de store Højtidsdage kører i Guldkaret, mens Guldæblerne springer i Fontænen på Gammeltorv. Og Alverdens Turister vil valfarte til Danmark for at se, hvordan det gik til i gamle Dage". ${ }^{36}$

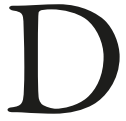
er var i Norge i 1905 en omfattende diskussion af, hvilken form den norske stat skulle have. I modsætning til 1814 var republikanismen en stærk bevægelse, der agiterede for, at opløsningen af den svensk-norske personalunion skulle resultere $i$ en norsk republik. Bjørnstjerne Bjørnsson agiterede for republik, men skiftede imidlertid holdning, for hvilket han høstede ros hos den danske regeringsleder, venstrehøvdingen J.C. Christensen:

"Det er klogt som De optræder i spørgsmålet om Norges statsform. Kan De huske, at jeg sidste vinter skrev til Dem, at alle tre lande måtte først være fuldt selvstændige og ligestillede, førend et rigtigt samarbejde kunne komme. $\mathrm{Nu}$ er Norge lige ved ligestilletheden, et sidste skridt, så er det nået. Men ligestilletheden nås kun gennem kongedømmet, $\mathrm{i}$ al fald $\mathrm{i}$ vor tid, og derfor er det så klogt og rigtigt, at De stiller Dem, som De gør og det skal De have min tak for ..." ${ }^{37}$

Argumentet var, at den nordiske balance først kunne opnås ved jævnbyrdighed, og det var Christensens vurdering, at det bedst kunne ske på monarkiets grund. 
Tre kongerpå altanen under modet i Malmo 1914. Det Kongelige Bibliotek, Billedsamlingen.

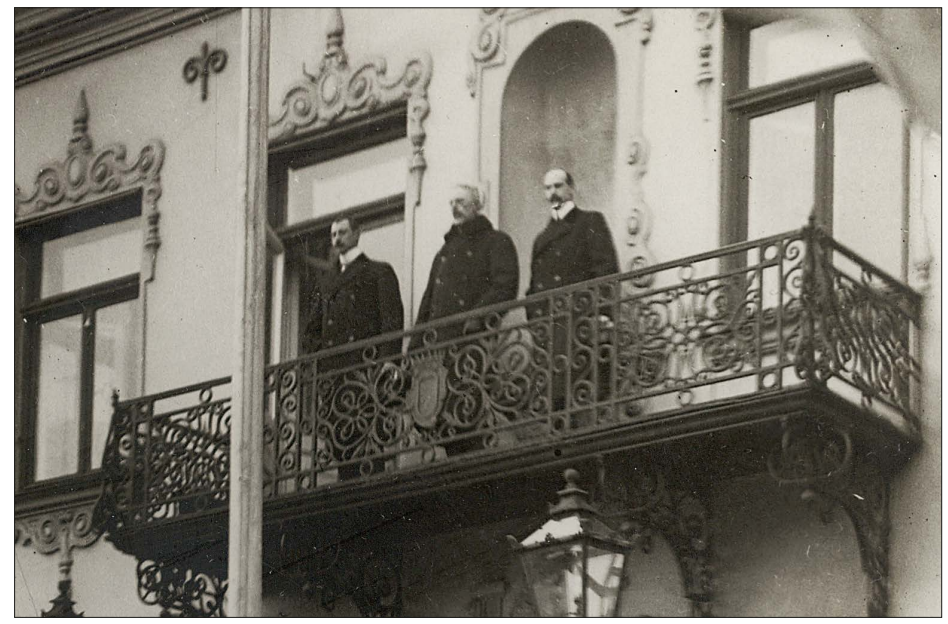

Christensen var bestemt ikke monarkist, men i høj grad pragmatiker. Den smidige tilpasning til den politiske situation blev i det 20. århundrede en overlevelsesbetingelse for en monark. Det var en lektie, som den svenske konge Gustav 5. lærte under den såkaldte Borggårdskrise i 1914, og som den danske Christian 10. lærte under den såkaldte Påskekrise i 1920. Begge kriser tilvejebragte i praksis, men ikke de jure, et fast hierarkisk forhold mellem statsoverhoved, regering og parlament, der blandt andet indebar, at regeringschefen stillede sig som garant for monarkiet, så længe monarken blandede sig uden om politik og i øvrigt rettede ind efter regeringschefen.

Efter Påskekrisen så også Stauning en fordel i fastholdelsen af monarkiet. Han var ganske vist som de fleste socialdemokrater dengang principielt tilhænger af republikken, men kun hvis han kunne skaffe sig sikkerhed for, at man kunne få en socialdemokrat som præsident. Så længe man risikerede at få J.C. Christensen som statschef, var det arbejdende folk bedre tjent med et monarki, mente
Stauning $\mathrm{i}$ et tilbageblik på begivenhederne i foråret $1920 .^{38}$

Som bl.a. Uffe Østergaard har peget på, blev Norden som en enhed bestående af fem nationalstater med den nuværende grænsedragning skabt inden for et ganske kort tidsrum: $1905-1920 .{ }^{39}$ Som J.C.

Christensen skrev, var det forudsætningen for etableringen af Norge som ligeværdig partner i et nordisk fællesskab, at det blev et monarki på linje med de to øvrige skandinaviske lande. Dermed blev den forestilling om "de nordiske Broderlande", som var kendt fra det 19. århundredes skandinavisme, virkeliggjort på en nærmest helt håndgribelig måde. Symbolsk fandt den sit stærkeste udtryk ved mødet mellem de tre skandinaviske monarker i Malmö i 1914. På mødet blev de nordiske landes neutralitetskurs drøftet mellem de tre landes udenrigsministre. Men det var også et møde mellem brødre. Christian 10. af Danmark og Haakon 7. af Norge var ganske enkelt brødre, og deres svenske kollega var deres mors fætter, idet enkedronning Lovisas far, Carl 15., og Gustav 5.'s far Oscar 2., var brødre. 
Anden fase af den nordiske forbrødring fandt sted få år senere i form af dannelsen af een personalunion og opløsningen af en anden. I $1918 \mathrm{blev}$ Island et monarki. Man ser det sjældent beskrevet således, men det var ikke desto mindre tilfældet. Mens flertallet af de nye stater, der blev dannet i det 20. århundrede, var republikker, hører Island til den sidste lille restgruppe af lande, der ved afslutningen af Første Verdenskrig fik deres selvstændighed i monarkiets form i kortere eller længere tid. Det gjaldt lande som Albanien, Jugoslavien, Saudi Arabien og altså Island. Der var for Islands vedkommende tale om resultatet af en længere og i hovedsagen fredelig proces. Unionen blev opløst stort set i mindelighed i 1944, da Island valgte at blive en republik. Den samme proces undergik Finland. Finland var ikke bare blevet opslugt af Rusland i 1808, men oprettet som et storfyrstendømme i personalunion med Rusland. I kølvandet på den russiske revolution i 1917 bredte den russiske borgerkrig sig også til Finland, der endte med at kunne løsrive sig som en republik. Nordens sydgrænse fik sin endelige form - selv om den var stærkt omstridt i samtiden - i 1920 ved Slesvigs deling, hvad danskerne normalt erindrer som Genforeningen. Det nationale princip for grænsedragning blev fulgt nærmest så præcist, som det lod sig gøre. Hermed opgav det glücksborgske kongehus formelt og reelt ethvert dynastisk krav på de gamle arvelande Slesvig og Holsten.

Selv om betydningen af de dynastiske bånd svandt betydeligt ind, kunne den tyske gesandt i Stockholm endnu i 1930, da den norske kronprins Olav giftede sig med den svenske prinsesse Märtha, berette hjem til Berlin om ægteskabet som en reel styrkelse af båndene mellem Norge og Sverige. ${ }^{40} \mathrm{Og}$ da den danske kronprins i 1935 giftede sig med den svenske prinsesse Ingrid, blev begivenheden set som endnu et udslag af nordisk forbrødring. Men det politiske indhold af de dynastiske forbindelser var for længst hørt op. I den næste generation blev det såkaldte jævnbyrdighedsprincip opgivet. De nuværende monarker i Danmark, Norge og Sverige har giftet sig under deres stand, den danske med en fransk, adelig diplomat af familien de Monpezat. Det har ingen betydning, for kongefamilien udleder ikke længere sin betydning eller legitimitet fra forældede forestillinger om "ublandet blåt blod". Og i dag kan man uden at risikere anklage om majestætsfornærmelse fortælle historien om, hvordan de dynastiske forbindelser mellem den svenske og danske kongefamilie er foregrebet af et gadekryds i byen Pau, hvor Rue Bernadotte skærer Rue de Monpezat, opkaldt efter prinsgemalens farfar, der var borgmester i byen. Til gengæld skal man ikke underkende betydningen af fænomenet personalunion. De britiske Commonwealth Realms er en personalunion af 16 monarkier - hvoraf de største er Canada, Australien og New Zealand som deler monark med det, der oprindeligt også var en personalunion, nemlig United Kingdom (skrevet mens Skotlands fremtidige statsretlige status endnu er uafgjort). Interessant i dansk sammenhæng er, at det, som vi kalder Rigsfællesskabet, i vid udstrækning kan forstås som en personalunion mellem Grønland, Færøerne og Danmark, og at fuld grønlandsk eller færøsk selvstændighed meget vel vil kunne fuldbyrdes ved republikkens udråbelse, hvorved mønstret fra Finlands og Islands selvstændighed blot ville blive gentaget. 


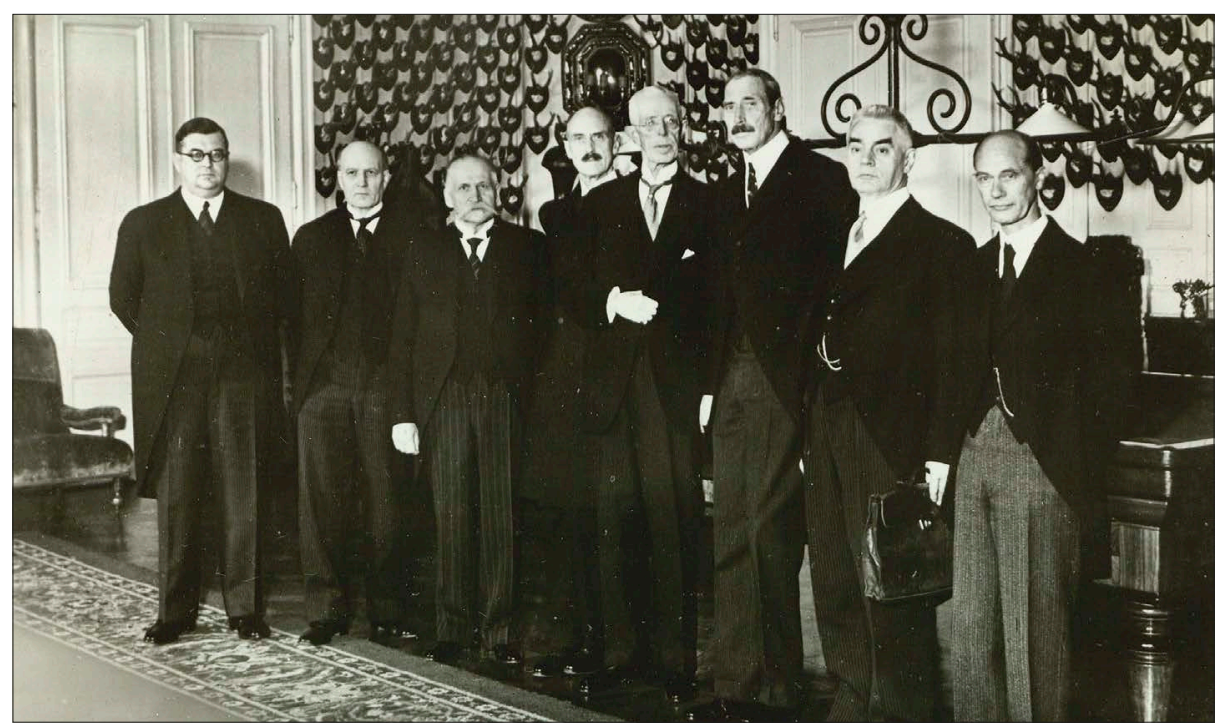

De tre nordiske konger og den finske president samt deres respektive udenrigsministre ved kongemodet i Stockholm den 18. oktober 1939. Det Kongelige Bibliotek, Billedsamlingen.

\section{Noter}

Hvor intet andet er nævnt bygger artiklen på min bog Dynastiet Glücksborg. 2013.

1 Immanuel Kant: Schriften zur Anthropologie, Geschichtsphilosophie und Pädagogik 1. 1993, s. 197.

2 Munch-Ræder, Den norske Statsforfatnings Historie og Vesen. 1841, s. 31.

3 Ola Mestad (red.): Frihetens forskole. Professor Schlegel og Eidsvollsmennenes læretid i København. Oslo 2013.

4 T. Nipperdey: Deutsche Geschicte 18001866. Bürgerwelt und starker Staat. München 1994, s. 11.

5 Harald Gustafsson: "Statsbildning och territoriel integration”, Scandia, LVII, 1991, s. 199f. Begrebet konglomeratstat optræder bl.a. s. 219.

6 En nyere undersøgelse viser også, at det tabstal, der figurerer i litteraturen er ganske betydeligt overdrevet. Ikke 2000, men blot ca. 200 civile måtte lade livet. Mia Miriam Lade Krogaard, "Bomberegnens følger”, i: P. Henningsen (red.) Kobenhavn 1807. Belejring og bombardement. 2007.
7 Per Sandin: Ett Kungahus i Tiden. Uppsala 2011.

8 C.A. Bayly: The Birth of the Modern World 1780-1914. Oxford 2004, s. 427.

9 Dieter Langewiesche: "Die Monarchie im Europa des bürgerlichen Jahrhunderts. Das Königreich Württemberg." In: Das Königreich Württemberg 1806-1918. Monarchie und Moderne. Ausstellungskatalog. Stuttgart 2006, s. 26.

10 Markus Prutsch: Making Sense of Constitutional Monarchy in Post-Napoleonic France and Germany. Basingstoke 2012, s. 70. Se også Martin Kirsch, Monarch und Parlament im 19. Jahrhundert, Göttingen 1999.

11 Louis XVIII: Mon dernier mot. Paris 1814, s. 12.

12 Brian Kjær Olesen, "Frækhed er frihedens grænse”, i: Ole Mestad (red.): Fribetens forskole. Professor Schlegel og Eidsvollmennenes læretid i København. Oslo 2013.

13 Jörn Leonhard, "Liberalisme i det tidlige 19. århundrede: En historisk semantik 
i tysk og europæisk perspektiv", i: Jeppe Nevers, Niklas Olsen og Casper Sylvest (red.): Liberalisme. Danske og internationale perspektiver. 2013, s. 78-79.

14 En af de tidligste forekomster af begrebet fri forfatning på dansk findes i Jens Møller: "Om Videnskabelighed og Moralitet", Theologisk Bibliothek, 9, 1816, s. 73.

15 Se også Pasi Ithalainen [et. al.] (red.): Scandinavia in the Age of Revolution. Nordic Political Cultures, 1740-1820. Farnham 2011.

16 Dr. N. Falck: Das Herzogthum Schleswig in seinem gegenwärtigen Verbältnis zu dem Königreich Dänemark und zu dem Herzogthum Holstein. Kiel 1816, s. 3.

17 U.J. Lornsen: Über das Verfassungswerk in Schleswigholstein. Kiel 1830, s. 3.

18 For en helt anden tolkning se f.eks. Michael Helm: Det kvalte demokrati. Guldalderens glemte systemkritikere. 1986, citatet s. 78.

19 Niels Petersen (udg.): Betenkninger fra Christian VIII's tid om styrelsen af det danske monarki. 1969, indledningen s. xvii.

20 Sst., s. 365.

21 Harald Jørgensen (udg.): Statsrådets Forhandlinger 1848-1863. 1954, bd. 1.s. 116.

22 Forfatningerne kan findes i faksimile på <www.modern-constitutions.de $>$. Betegnelsen for styreformen blev bevaret $\mathrm{i}$ unionsforfatningens første paragraf.

23 Tim Knudsen: Fra enevelde til folkestyre. 2006, s. 118.

24 Indskrænket monarki (monarchia limitata) blev dannet som begreb i tidlig moderne tid hos tænkere som Hugo Grotius og Samuel Pufendorf parallelt med og som reaktion på det absolutte eller uindskrænkede monarki (monarchia absoluta), se Horst Dreitzel: Monarchiebegriffe in der Fürstengesellschaft. Köln 1991, bd. 1 s. $82 \mathrm{ff}$.

25 Kongeriget Norges Grundlov. Christiania: Jacob Lehmann 1814, s. 38f. Faksimile efter <www.modern-constitutions.de $>$.

26 Harald Jørgensen: Trykkefribedssporgsmålet i Danmark 1799-1848. 1944.
27 Carsten Jahnke og Jes Fabricius Møller (red.): 1864 og historiens lange skygger / 1864 und der lange Schatten der Geschichte. 2011.

28 Se Erik Møller: Helstatens fald. 1958, bd. 1, s. 24, og Steen Bo Frandsen: Holsten $i$ helstaten. 2008, s. 251.

29 Neergaard, I, s. 705.

30 Rasmus Glenthøj: 1864 - Sønner af de Slagne. 1914. Herom se også Erik Møller: Skandinavisk Streben og svensk Politik omkring 1860. 1948.

31 Aage Friis: "Skandinavismens Kulmination. Ministeriet Halls Planer om en nordisk Union forud for Martskundgørelsen 1863", Historisk Tidsskrift, 3. rk., 10, 1934. Se også Oscar II: Mina Memoarer. Stockholm 1962, bd. III, s. 85, noten. Sml. Claus Bjørn: Blot til pynt?Monarkiet i Danmark - i gar, i dag og i morgen. 2001, s. 138.

32 Således huskede prinsessen det i hvert fald mange år senere. Tor Bomann-Larsen: Kongstanken. Haakon og Maud, bind 1. Oslo 2001, s. 42.

33 Uffe Østergaard: "The Geopolitics of Nordic Identity”, in: Stråth og Sørensen (eds.): The Cultural Construction of Norden. Oslo 1997, s. 38ff.

34 Boman Larsen: Folket. Haakon \& Maude. Bind II. Oslo 2004.

35 Jørgen Haugan: "København som Norges kulturelle hovedstad", i: Fl. LundgreenNielsen (red.) : København - lest og påskrevet. 1997.

36 Citeret efter Trond Noren Isaksen i Politikens kronik 28. marts 2010.

37 Brev af 10. oktober 1905, cit. efter Poul Duedahl: J.C. Christensen. Et politisk menneske. 2006, s. 234.

38 Henning Grelle: Thorvald Stauning. 2008, s. 258.

39 Østergaard: Anf. arb., s. 45.

40 W. Becker (Hrsg.): Frederic von Rosenberg. Korrespondenzen und Akten des deutschen Diplomaten und Aussenministers 19131937. Oldenbourg 2011, s. 425. 